\title{
Variation in Onset of Leaf Unfolding and Wood Formation in a Central African Tropical Tree Species
}

\section{OPEN ACCESS}

Edited by:

Veronica De Micco,

University of Naples Federico II, Italy

Reviewed by:

Romà Ogaya,

Ecological and Forestry Applications Research Centre (CREAF), Spain

Achim Braeuning,

University of Erlangen-Nuremberg,

Germany

*Correspondence:

Bhely Angoboy llondea

Bhely.Angoboyllondea@ugent.be

Specialty section: This article was submitted to

Forest Growth,

a section of the journal Frontiers in Forests and Global

Change

Received: 27 February 2021 Accepted: 20 September 2021 Published: 15 October 2021

Citation:

Angoboy llondea $B$, Beeckman $H$, Van Acker J, Van den Bulcke J,

Fayolle A, Couralet C, Hubau W, Kafuti $C$, Rousseau M,

Kaka di-Makwala A, Bourland N, Deklerck V, Kasongo Yakusu E,

Ewango $C$ and De Mil T (2021)

Variation in Onset of Leaf Unfolding and Wood Formation in a Central

African Tropical Tree Species.

Front. For. Glob. Change 4:673575.

doi: 10.3389/ffgc.2021.673575
Bhely Angoboy llondea1,2,3*, Hans Beeckman'2, Joris Van Acker ${ }^{3}$, Jan Van den Bulcke ${ }^{3}$, Adeline Fayolle ${ }^{4}$, Camille Couralet,2,3, Wannes Hubau',3, Chadrack Kafuti2,3,5, Mélissa Rousseau², Alain Kaka di-Makwala1 , Nils Bourland ${ }^{2,6,7}$, Victor Deklerck ${ }^{2,8}$, Emmanuel Kasongo Yakusu ${ }^{2,3,9}$, Corneille Ewango ${ }^{9}$ and Tom De Mil',3,4

${ }^{1}$ Institut National pour l'Etude et la Recherche Agronomiques, Kinshasa, Democratic Republic of Congo, ${ }^{2}$ Royal Museum for Central Africa, Wood Biology Service, Tervuren, Belgium, ${ }^{3}$ Laboratory of Wood Technology (UGent-Woodlab), Department of Environment, Ghent University, Ghent, Belgium, ${ }^{4}$ Forest is Life, TERRA Teaching and Research Centre, Gembloux Agro Bio-Tech, University of Liège, Liège, Belgium, ${ }^{5}$ Department of Natural Resources Management, Faculty of Agricultural Sciences, University of Kinshasa, Kinshasa, Democratic Republic of Congo, ${ }^{6}$ Center for International Forestry Research, Bogor, Indonesia, ${ }^{7}$ Resources \& Synergies Development Pte., Ltd., Singapore, Singapore, ${ }^{8}$ Royal Botanic Gardens, Kew, Richmond, United Kingdom, ${ }^{9}$ Faculty of Renewable Natural Resources Management, University of Kisangani, Kisangani, Democratic Republic of Congo

A diversity of phenological strategies has been reported for tropical tree species. Defoliation and seasonal dormancy of cambial activity inform us on how trees cope with water stress during the dry season, or maximize the use of resources during the rainy season. Here, we study the matching between leaf phenology (unfolding and shedding) and cambial activity for Prioria balsamifera, a key timber species in the Democratic Republic of Congo. In particular, we (i) evaluated the seasonality of cambial activity and synchrony of phenology among trees in response to climate and (ii) identified the seasonality of leaf phenology and its relation with cambial phenology. The study was conducted in the Luki Man and Biosphere Reserve, located in the Mayombe forest at the southern margin of the Congo Basin. Historic defoliation data were collected every ten days using weekly crown observations whereas recent observations involved timelapse cameras. Cambial pinning was performed on ten trees during 20 months and radius dendrometers were installed on three trees during 13 months. Tree rings were measured on cores from 13 trees and growth synchrony was evaluated. We found that $P$. balsamifera defoliates annually with a peak observed at the end of the dry season and the beginning of the rainy season. The new leaves unfolded shortly after shedding of the old leaves. The peak defoliation dates varied across years from September 12 to November 14 and the fraction of number of trees that defoliated at a given time was found to be negatively correlated with annual rainfall and temperature; during the dry season, when precipitation and temperatures are the lowest. Wood formation (radial growth), was found to be highly seasonal, with cambial dormancy occurring during the dry season and growth starting at the beginning of the rainy season. Individual ringwidth series did not cross date well. The within species variability of leaf phenology and cambial rhythms provides indication about resistance of the population against climatic changes.

Keywords: deciduousness, leaf and cambium phenology, Prioria balsamifera, Mayombe forest, seasonality, synchrony 


\section{INTRODUCTION}

The effects of global change are already impacting forest ecosystems in terms of vegetation structure and floristic composition (Carrer, 2011). Understanding the sensitivity of tropical forests and species to climate change is becoming increasingly important (Hubau et al., 2020).

Phenology is a key variable herein, specifically to understand how trees cope with the dry season, and how they will respond to increased future droughts. The phases of leaf unfolding and defoliation of trees affect photosynthetic activity by drought response and the trade-off between the risks of carbon starvation (if there is no photosynthetic activity because of leaf shedding) and hydraulic failure (if stomata are maintained opened), which on their turn affect primary and secondary growth, survival and productivity of trees (Lisi et al., 2008). Tree mortality is an important component of forest dynamics. It is one of the vital rates of a forest community, next to regeneration and tree growth. Knowledge of the physiological mechanisms that cause tree mortality due to drought is important for documenting tree responses to environmental changes. Two different physiological mechanisms can cause tree mortality: hydraulic failure and carbon starvation. Plant death by hydraulic failure is observed when increased tension causes air bubbles in the sap flow resulting in cavitation and embolism. Carbon starvation occurs when plants close their stomata to minimize water losses, thereby also reducing carbon uptake and photosynthesis. A carbon deficit arises, maintenance of metabolism is not possible anymore, leading eventually to the death of the tree (Sevanto et al., 2014). A diversity of leaf phenology strategies has been reported for tropical tree species (Newstrom et al., 1994). Two major leaf habits are, however, generally distinguished, i.e., the evergreen habit, defined by the retention of functional leaves in the canopy throughout the year versus the deciduous habit for which a tree is leafless for some part of the annual cycle (Kikuzawa and Lechowicz, 2011).

Tropical trees can reduce the impact of seasonal drought by adaptive mechanisms such as defoliation or stem succulence and by using soil water reserves, which enables an evergreen canopy during periods of low rainfall (Borchert, 1998). In addition, the cambial activity decreased during the dormant period (Zang et al., 2014). Seasonal drought often leads to defoliation of trees (Lloret et al., 2004; Bréda et al., 2006; Couralet et al., 2013; Fétéké et al., 2016) and subsequent reductions in tree-ring growth (Millar et al., 2007). Depending on the impact of the drought, subsequent rains may allow canopy greenness and carbon uptake to recover, with a corresponding increase in tree-ring growth. The leaf phenology helps to enhance the resilience to drought by reducing Leaf Area Index (LAI) at the end of the wet season, thus saving soil water for the upcoming dry months (Manoli et al., 2018). Growth cessation during the dry season also demonstrates the tree's resilience to climatic variations.

Radial growth is often monitored through repeated measurements in permanent sample plots (Lewis et al., 2019; Angoboy Ilondea et al., 2020; Hubau et al., 2020) but dendrochronological analysis can complement successive growth measurements in permanent sample plots with added precision
(Swetnam et al., 1999; Angoboy Ilondea et al., 2020). A sound interpretation of growth patterns of tropical trees depends on understanding phenological rhythms (Enquist and Leffler, 2001) at the primary (apex growth, leaf unfolding) and secondary meristem level (cambium, wood formation) (De Mil et al., 2019).

Most research on seasonality of cambial activity in the tropics has been performed in South America and in South-East Asia. In the tropical rainforest of French Guiana, the cambial activity of two dominant tree species was significantly reduced during the leafless period, irrespective of rainfall (Morel et al., 2015). In contrast, in Colombia, Herrera-Ramirez et al. (2017) observed a successfully crossdated tree-ring series in Prioria copaifera Griseb. However, the ring series did not show a signal for mean annual rainfall and temperature. In Thailand, cambial activity varied significantly between species, ranging from being active right on the transition from the dry season to the wet season, to peak activity in the midst of the wet season (Pumijumnong and Buajan, 2013).

Studies on seasonality of cambial activity in species from the Congo Basin are, however, limited (Beeckman, 2016). In addition to the response to seasonal drought, radial growth has been found to vary according to light requirements (Couralet et al., 2013; Hubau et al., 2019). A detailed study on three commercial species showed that growth rings were anatomically distinct, annual and closely modeled by cambial seasonality in Cameroon (Fétéké et al., 2016). Couralet et al. (2010) and De Mil et al. (2017) used cambial pinnings for monitoring cambial activity of understory species in the Luki Man and Biosphere Reserve, in the Democratic Republic of Congo (DRC). Both studies showed that growth is related to variations in the environment and mainly to variations in precipitation.

The existence of annual growth rings that are associated to climate seasonality, primarily to rainfall (Worbes, 1999) is mostly limited to deciduous species growing in the canopy with their crowns fully exposed to external environmental factors (Pumijumnong and Park, 1999; Worbes, 1999). Successful crossdating of ring-width series denotes consistent and synchronous patterns of variation and indicates that a common external factor controls ring formation in different trees (Singh and Venugopal, 2011). In most tropical regions (and especially DRC) exactly dated reference chronologies are not available, so crossdating consists of comparing growth curves of different trees visually and statistically to synchronize ring-width series. A lack of growth synchrony of trees from the same species is an important aspect of diversity and adds to the resilience capacity of a population (Worbes, 1999). The lack of crossdating indicates that individuals of the same species in the same environment would react differently to a disturbance. In extreme cases where many individuals are killed by stressful growth conditions, the population can potentially recover thanks to individuals that survived because they are less susceptible to the environmental stressors. Camarero et al. (2015) considered increases in synchronicity among trees as an early warning signal for increased sensitivity to drought and augmented vulnerability of populations of Scots pine (Pinus sylvestris) and Aleppo pine (Pinus halepensis). Tree-to-tree growth synchronicity indeed often increases with drought stress (Fritts, 2001) or other 
unfavorable conditions. Hence, a population with diverse growth patterns can be assumed to be more resilient.

In this work, we contribute to understand the resilience of Prioria balsamifera (Vermoesen) Breteler (FabaceaeCaesalpinioïdeae) in the Mayombe forest based on an analysis of synchrony of defoliation and cambial activity by: (i) evaluating the seasonality of cambial activity and synchronicity in response to climate and (ii) identifying the seasonality of leaf phenology. To do so, we used series of growth rings from cambial marks from 1947 to 2014, intra-annual cambial marks from the season of 2006-2007, and dendrometer data from 2017 to 2018, observations of inter-annual defoliation from 1947 to 1957, time-lapse camera observations of defoliation from 2015 to 2016, and measured tree-ring width series (1811-2014). We studied $P$. balsamifera, a commercial tree species under strong pressure from logging to supply local artisanal markets. $P$. balsamifera is one of the main species of the timber industry in the DRC. It is a brevi-deciduous species, reaching $55 \mathrm{~m}$ in height and $1.5 \mathrm{~m}$ in diameter, with a spherical crown and open foliage (Arno, 2001; Meunier et al., 2015).

\section{MATERIALS AND METHODS}

\section{Study Site}

The Luki Man and Biosphere Reserve is located in the southwest of the DRC (latitude between $05^{\circ} 35^{\prime}$ and $05^{\circ} 43^{\prime} \mathrm{S}$, longitude between $13^{\circ} 10^{\prime}$ and $13^{\circ} 15^{\prime} \mathrm{E}$ ), in the Kongo Central province at $120 \mathrm{~km}$ from the Atlantic coast. It belongs to the Mayombe forest which constitutes the southern margin of the GuineoCongolese forests (Lubini, 1997). It is considered representative of the Mayombe flora (Lubini, 1997) and classified as "Central African moist forest” (Fayolle et al., 2014). Soils are ferralitic, acidic with a low cation content (Sénéchal et al., 1989).

The climate is moist tropical and corresponds to type $\mathrm{Aw}_{4}$ of the Köppen classification (Peel et al., 2007). It is influenced by the cold oceanic current of Benguela and the southeast winds, also due to its proximity to the Atlantic coast (Lubini, 1997; Couralet et al., 2010). In the Luki Man and Biosphere Reserve, rainfall and temperature are being recorded since 1948 (Couralet et al., 2013; Angoboy Ilondea et al., 2019). The daily data collected onsite show a strong inter-annual variation of rainfall with an average of $1,201 \mathrm{~mm} \cdot$ year $^{-1}$ and a standard deviation of $323 \mathrm{~mm}$ from 1947 to 1958 . This is very low for dense forest sites, so cloud cover in the morning during the dry season is probably a key factor to maintain forest cover there. The seasonality of rainfall is bimodal, with two rainy seasons interspersed with a large and very marked dry season (June-September), and to a much lesser extent during December-January (Figure 1), where rainfall is less pronounced in amplitude and intensity (Angoboy Ilondea et al., 2019).

\section{Tree-Ring Measurements and Wood Formation}

A total of 194 trees of $P$. balsamifera nail tagged with metal plates by the Institut National pour l'Étude Agronomique du Congo Belge (INEAC), later renamed Institut National pour

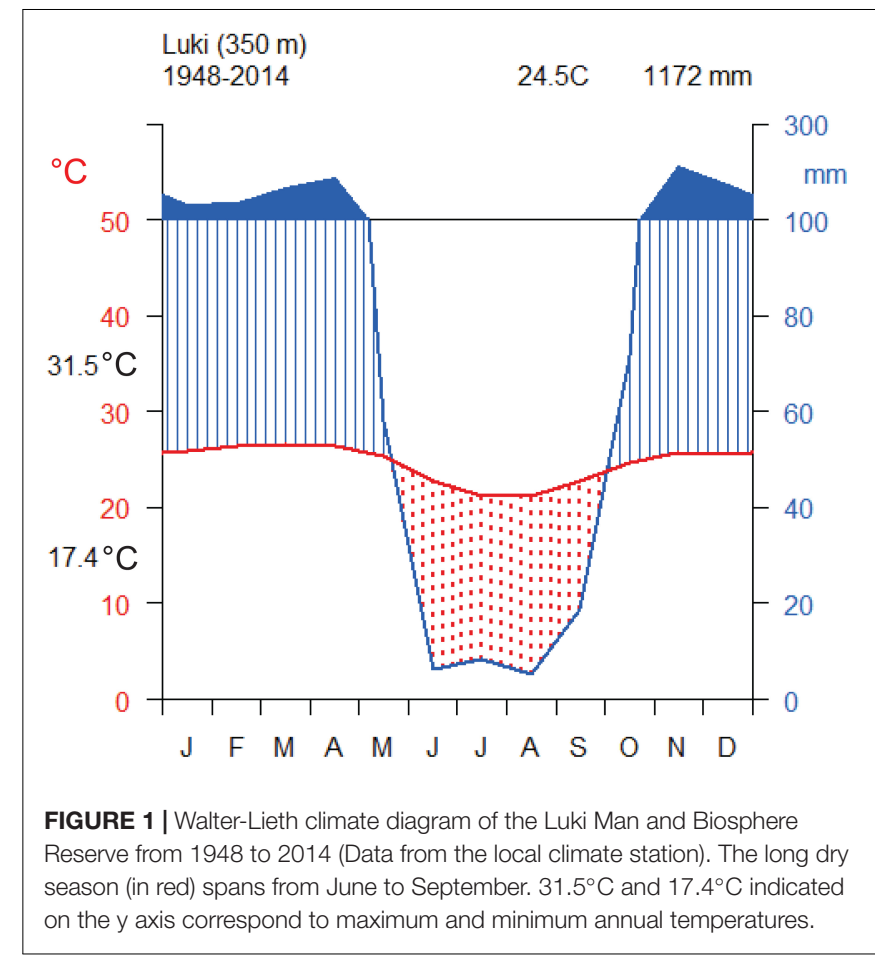

l'Etude et la Recherche Agronomiques en R.D. Congo (INERA) at the end of 1947 were monitored for phenology between 1947 and 1958 (Couralet et al., 2013; Angoboy Ilondea et al., 2019). Wood samples were collected from the nail area in 2014 for 13 trees that showed a clear nail trace. A selection of increment cores or stem fragments was made, based on whether clear wood markings were visible after sanding (Hubau et al., 2019). For every core, growth-ring series were visualized using imaging methods as previously described in De Mil et al. (2016). Core surfaces were smoothed with a core microtome (Gärtner and Nievergelt, 2010) and scanned using a flatbed scanner at $2400 \mathrm{dpi}$ (EPSON Perfection 4990 PHOTO). Rings formed between 1948 and 2014 were measured on the stem fragments and cores using a LINTAB measuring stage in combination with TSAP-Win ${ }^{\text {TM }}$ software (Rinntech, Germany), as well as with the DHXCT graphical user interface (De Mil et al., 2016), available on www.dendrochronomics.ugent.be.

Every first week of the month between April 2006 and August 2007, cambial pinning was performed on the stem, each new mark was made $5 \mathrm{~cm}$ to the right in a spiral arrangement to avoid interference of nearby wound tissue. When a circumference was fully occupied, the next pinnings were made on a new circumference $20 \mathrm{~cm}$ higher. The diameter of these trees varied between 15.4 and $40.8 \mathrm{~cm}$. After 20 months, we obtained the proper authorization to cut the trees that were monitored. Stem sections were sawn at the level of the markings visible on the bark and all pinning positions were indicated with paint. Samples were air-dried and then cut into small pieces, each containing one wound. The surface was sanded with gradually increasing grid from 50 to 600 or 1200 and the different wood tissues were observed macro-and microscopically (Couralet et al., 2013). 
Finally, from 2016 to 2017, electronic radius dendrometers (EcoMatik) were mounted on three trees of $P$. balsamifera to account for daily variations in stem diameter, and as an additional verification for cambial growth. The dendrometers were installed at $1.30 \mathrm{~m}$ height and stem diameter variations (SDVs) were logged every 30 min using ONSETComp HOBOloggers (Onset; De Mil et al., 2019).

\section{Defoliation Data}

A total of 194 trees of $P$. balsamifera were monitored for phenology every 10 days from 1947 to 1958, and phenological observations, i.e., the presence of flowers, fruits, dissemination and defoliation in the crown, were reported in notebooks. These historical phenology data have been previously analyzed (Couralet et al., 2013; Angoboy Ilondea et al., 2019). More recently, leaf unfolding was daily monitored for two trees using Wingscapes time-lapse cameras (Alberton et al., 2017), the pictures were taken from 6 a.m. to 6 p.m. at an interval of $1 \mathrm{~h}$. The time-lapse cameras were operational from December the 14th, 2015 to September the 16th, 2016, thus covering one entire dry season. The images were visually analyzed and four defined leaf unfolding stages were identified: buds swelling, buds break, buds open and leaf unfolding adapted from Malaisse (1964). The occurrence of each leaf unfolding stages is compared with the corresponding season.

\section{Data Analysis}

All analyses were performed in R Studio ( $\mathrm{R}$ Core Team, 2016). Tree rings series were analyzed with the $\mathrm{R}$ package "dplR" (Bunn, 2008, 2010), defoliation with the R package "Circular" (Morellato et al., 2000) and the cambial pinning data by fitting a Gompertz function.

Relative growth rate (RGR) (\%) within the growing season was calculated to obtain growth curves of seasonal wood formation, given that variability of absolute growth along the circumference can be too high to construct a growth curve that is typical of the individual (Seo et al., 2007; De Mil et al., 2017). The Gompertz equation defined as follows was fitted to the data for each tree separately $(n=10$ for cambial pinning and $n=3$ for radius dendrometers).

$$
R G R=a e^{-e^{\beta-k t}}
$$

$R G R$ is the relative growth rate (in \%), $a$ is the upper asymptote, $\beta$ is the $\mathrm{x}$-axis placement for the location of the origin, $k$ stands for the rate of change parameter and $t$ is the time, expressed in number of days since the first cambial pinning.

\section{Tree-Ring Analysis}

We attempted to crossdate 13 cores from 13 trees, but of these, only 3 had 66 rings between 1948 and 2014, so all the others could not have been crossdated since there are too many missing rings. The function "interseries.cor" of the R package "dplR" has been used (Bunn, 2008, 2010). The three trees were located at the same slope and altitude. The signal strength and confidence of these series is assessed by calculating inter-series correlation (Rbar; Wigley et al., 1984). Successful crossdating of ring-width series denotes consistent and synchronous patterns of variation (Cook and Kairiukstis, 1990). Crossdating was performed visually in combination with a correlation analysis using Cofecha software (Holmes, 1983).

\section{Seasonality of Defoliation}

Using the crown observation data from 1947 to 1957, circular statistics allowed to detect and to test the synchrony of defoliation at the population level (all trees) and separately for individual trees between years. This also allowed quantifying the degree of temporal aggregation of defoliation (Davies and Ashton, 1999). The length of the vector rho (ranging from 0 to 1 ) indicates the duration and the concentration of phenological events. This vector was calculated for the species. In both cases, a lower rho value indicates a phenological activity occurring several times per year. A rho value close to 1 indicates a phenological event occurring once a year. Rayleigh uniformity test was performed to test the significant aggregation of defoliation events (Davies and Ashton, 1999).

We then tested the correlation between the percentage of trees showing defoliation (1947-1957) with the rainfall and temperature of the same period using the Pearson's correlation coefficient. This makes it possible to define the potential influence of the variation in precipitation and temperature on the defoliation.

\section{RESULTS}

\section{Wood Formation and Timing of Leafing Recorded by Time-Lapse Cameras}

The cambium of $P$. balsamifera is dormant from the end of the dry season and growth starts at the beginning of the rainy season in October (Figure 2). This was also detected by the cambial pinning and by the dendrometer measurements that follow the tree growth with higher resolution and accuracy. Growth rings are not always annual and are generally formed during the rainy season as illustrated by the Gompertz fit to show relative growth for all trees (Figure 2).

The maximum time between the development stages of leaf buds (Figure 2C) is about 7 days. Time-lapse camera photos, taken between December 14, 2015 to September 16, 2016, have indicated that the leaf unfolding is often short and all phenological stages of the leaves of one tree occur in only 1 week and confirmed the short defoliation episodes detected by circular statistics using the data of 1947-1957 (Figure 4). Analysis of camera's pictures has shown that the leaf unfolding follows shortly after the defoliation. Analysis of the camera's pictures has shown the leaf unfolding starts before the rainy season (July, August, and September) and continues until October. Leaf unfolding and defoliation are overlapping (Figure 2). The gray zone indicates the dry season (Figure 2C). The pictures from the time-lapse camera during the onset of leafing in July/August 2016 showed the development stages adapted to the characterization of Malaisse (1964): (a) old leaves, (b) stage 0: dormant buds, (c) stage I: buds swelling, (d) stage II: bud break, (e) stage III: buds open, (f) stage IV: leaf development. 


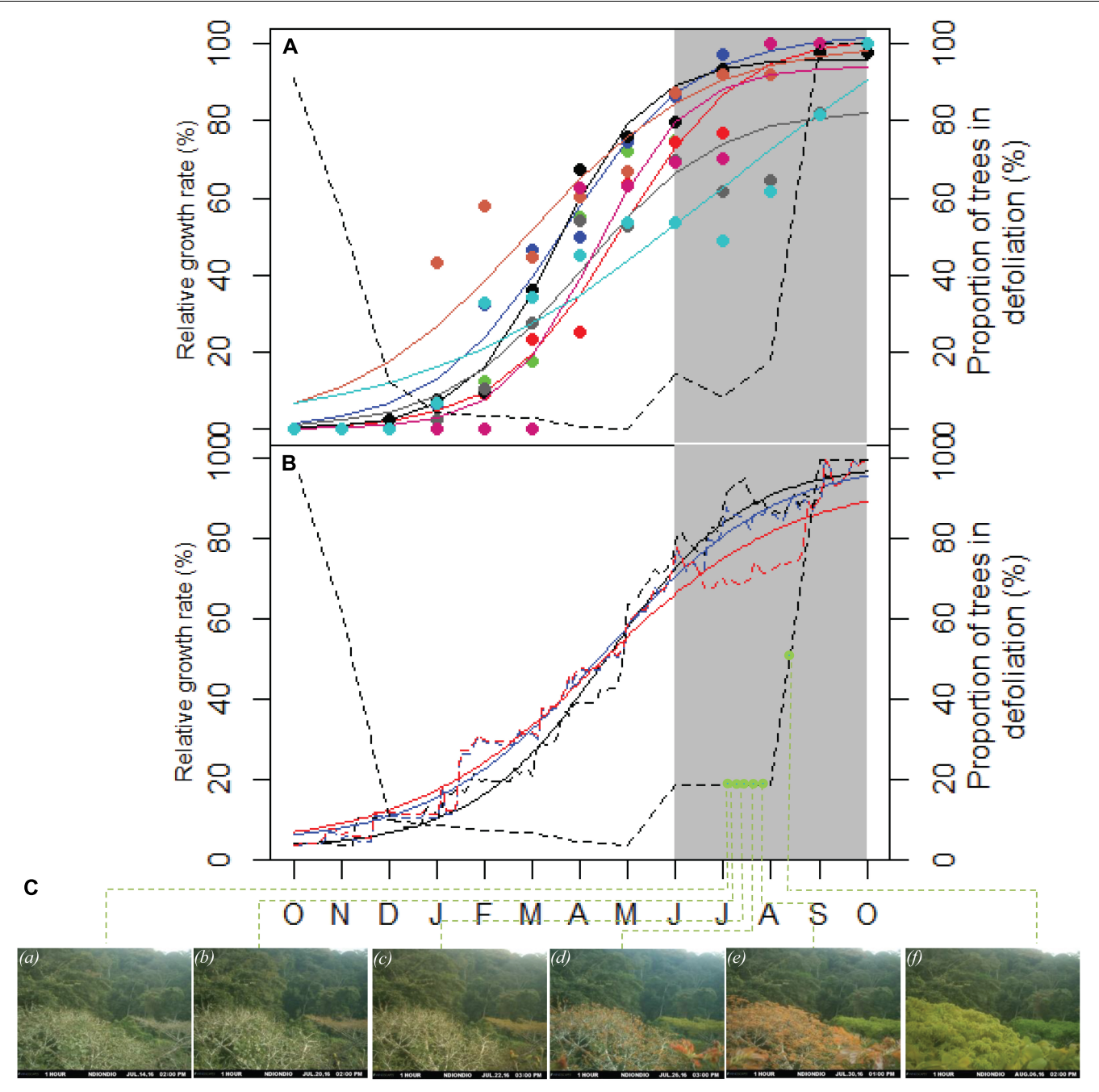

FIGURE 2 | Intra-annual growth dynamics of Prioria balsamifera: (A) lines represent the Gompertz fit based on circle points that indicate the growth measurement based on cambial pinning of 10 trees monitored from 2006 to 2007 ( $n=10$ trees). The dashed black line indicates time series of defoliation for 194 trees of P. balsamifera from 1947 to 1957. (B) The three lines represent the Gompertz fit assessed by point dendrometers from 2016 to 2017 ( $n=3$ trees) and the dashed lines indicate the original series. The black dashed line shows the defoliation form time-lapse camera. The gray zone indicates the dry season. (C) The pictures from the time-lapse camera shows the development stages $(a-f)$ during the onset of leafing in July/August 2016.

\section{Tree-Ring Crossdating}

Core images and ring-width data for $P$. balsamifera were extracted from Hubau et al. (2019). Cambial marks due to tree tagging indicated the year 1948 and thus serve as an absolute dating point. From these 13 trees (showing on average 111 rings from the pith onward), only the 3 trees for which we counted 66 rings between 1948 and 2014 (Figure 3) were retained. For these three trees (Figure 3B), the peak of defoliation was observed on October 10 (Tw77843), September 7 (Tw77847) and October 20 (Tw77877).

\section{Seasonality and Asynchrony in Leaf Phenology}

In addition to the 1 year leaf phenology monitoring campaign with time-lapse cameras, we used historical phenological observation data and we found that, every year a peak of defoliation was observed at the end of the dry season and the beginning of the rainy season. The peak dates varied across years from September 12 to November 14. Over the 11 years of phenology observations, peaks of defoliation were obtained in November for 5 years (1952-1955) and 1957, in September for 4 years $(1947,1949-1951)$ and in October for 2 years (1947 and 1956). The defoliation of P. balsamifera at the population level can thus be characterized as annual and irregular and of short duration (rho generally close to 1, Figure 4). Globally, the rho values of defoliation $(r h o>0.5)$ indicate the high degree of synchronization for the studied $P$. balsamifera population each year. The trees begin to lose their leaves mainly in the dry season and achieve a complete loss at the beginning of the rainy season. However, in 1955, the defoliation was not synchronous and was relatively spread out $(r h o=0.47)$ in contrast to the year 1952 


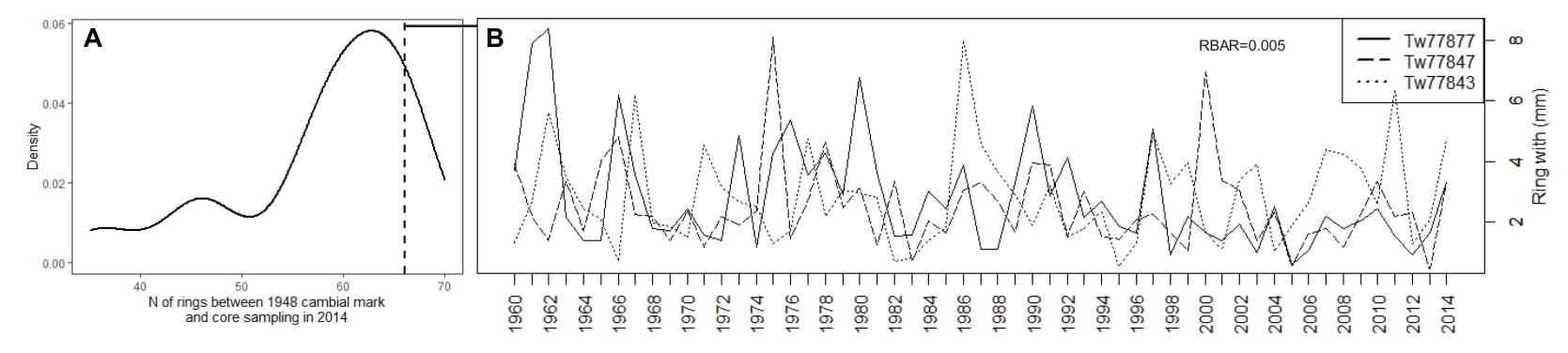

FIGURE 3 | (A) Distribution with number of rings formed in P. balsamifera between 1948 and 2014 (data from Hubau et al., 2019 ) where (B) cores with annual rings were retained and ring series were plotted with the crossdating parameters showing the lack of inter-series correlation. Rings before 1960 were removed to avoid effects of wound tissue.

which corresponds to a synchronous and very brief defoliation $(r h o=0.94)$. The lower number of defoliated trees is observed between 1952 and 1954.

Negative correlation were observed between the maximum number of defoliated trees and both annual rainfall and mean temperature $(P>0.05)$.

\section{DISCUSSION}

\section{Cambial Phenology and Lack of Crossdating}

Our results show that cambial phenology of $P$. balsamifera is dormant during the dry season and growth starts at the beginning of the rainy season (Figure 2). The first rains often trigger radial growth as already shown for other species using cambial pinning in the Mayombe forest: Aidia ochroleuca (K.Schum.) (Couralet et al., 2010), Terminalia superba Engl. \& Diels (De Ridder et al., 2013), Greenwayodendron suaveolens (Engl. \& Diels) Verdc. (De Mil et al., 2017). De Mil et al. (2019) detected that Terminalia superba Engl. \& Diels begins unfolding its leaves well before the rainy season, whereas dendrometer data complemented with cambial pinning showed that the wood is being formed after the first rains. Likewise, pre-rain green-up has been found to be ubiquitous across (sub) tropical savannas and woodlands of southern Africa (Trouet et al., 2012; Ryan et al., 2017).

The lack of crossdating (Figure 3, RBAR $=0.005$ ) indicates that climate response of $P$. balsamifera is not obvious. Nevertheless, the sensitivity values of individual series are above 0.2 , which is generally accepted as a series that might be sensitive enough for climate reconstruction (Tang et al., 2018).

\section{Leaf Phenology Related to Environmental Factors}

The defoliation of P. balsamifera is annual, but quite irregular from year to year (Figure 4), which has also been shown for other populations of trees (Newstrom et al., 1994).

Defoliation occurs during the dry season (July and August) but the new leaves appear rapidly after defoliation. The impact of the dry season on the seasonal functioning of tropical trees has already been studied for Terminalia superba Engl. \& Diels, in DRC (De Mil et al., 2019) and across the tropics
(Wagner et al., 2014). During seasonal drought, many trees renew their leaves and suspend their radial growth. In our study area, this phenomenon does not seem to be as important because the air humidity always remains high, even during the dry season because of the Benguela current (Lubini, 1997; Couralet et al., 2013; Angoboy Ilondea et al., 2019; Aleman et al., 2020). Therefore, the cambial dormancy period might be less strict than in other tropical regions with a more seasonal climate. In the Luki Man and Biosphere Reserve there are at least 3 months with less than $50 \mathrm{~mm}$ of rainfall each year, but the dense cloud cover as a result from the proximity of the ocean and the hilly landscape provides a constant high level of air humidity (Lubini, 1997).

It has been reported earlier that the tropical rainforests characterized by a strong annual dry season show an adjustment in leaf production and defoliation (Reich, 1995). Our results show a consistent yearly defoliation: trees leafing early in 1 year also do so in other years (Figure 4). However, the results indicate that there is a considerable variation between trees in a single year. The use of time-lapse cameras allowed a detailed monitoring of the leafing process (from the first buds to the complete new leaves) that occurs on a relatively short period of time, one single week, possible due to the high humidity. Such quick processes are not detected using crown observations, classically used for phenology monitoring, and done every 10 days (Angoboy Ilondea et al., 2019) but more generally only once a month (Bush et al., 2017). The lower number of defoliated trees between 1952 and 1954 was observed by Couralet et al. (2013) in the Luki Biosphere Reserve for flowering, fruiting and dissemination. This would be due to the very low rainfall in 1953 and 1954 caused by an El Niño event. They indicated that annual rainfall sums were slightly above average in 1948 and 1949 (1268 and $1260 \mathrm{~mm}$, respectively) and extremely high in $1950(1845 \mathrm{~mm})$.

\section{Asynchrony in Buffering Climate Change and Population Resilience}

Asynchronous leaf and cambial phenology has been earlier observed for the same site for Terminalia superba (De Mil et al., 2019), which confirms what is shown here for P. balsamifera. The dendrometers showed that the wood growth of T. superba starts after budburst between November and January (De Mil et al., 2019). Cambial pinnings confirmed that P. balsamifera growth starts at the beginning of the rainy season in October 


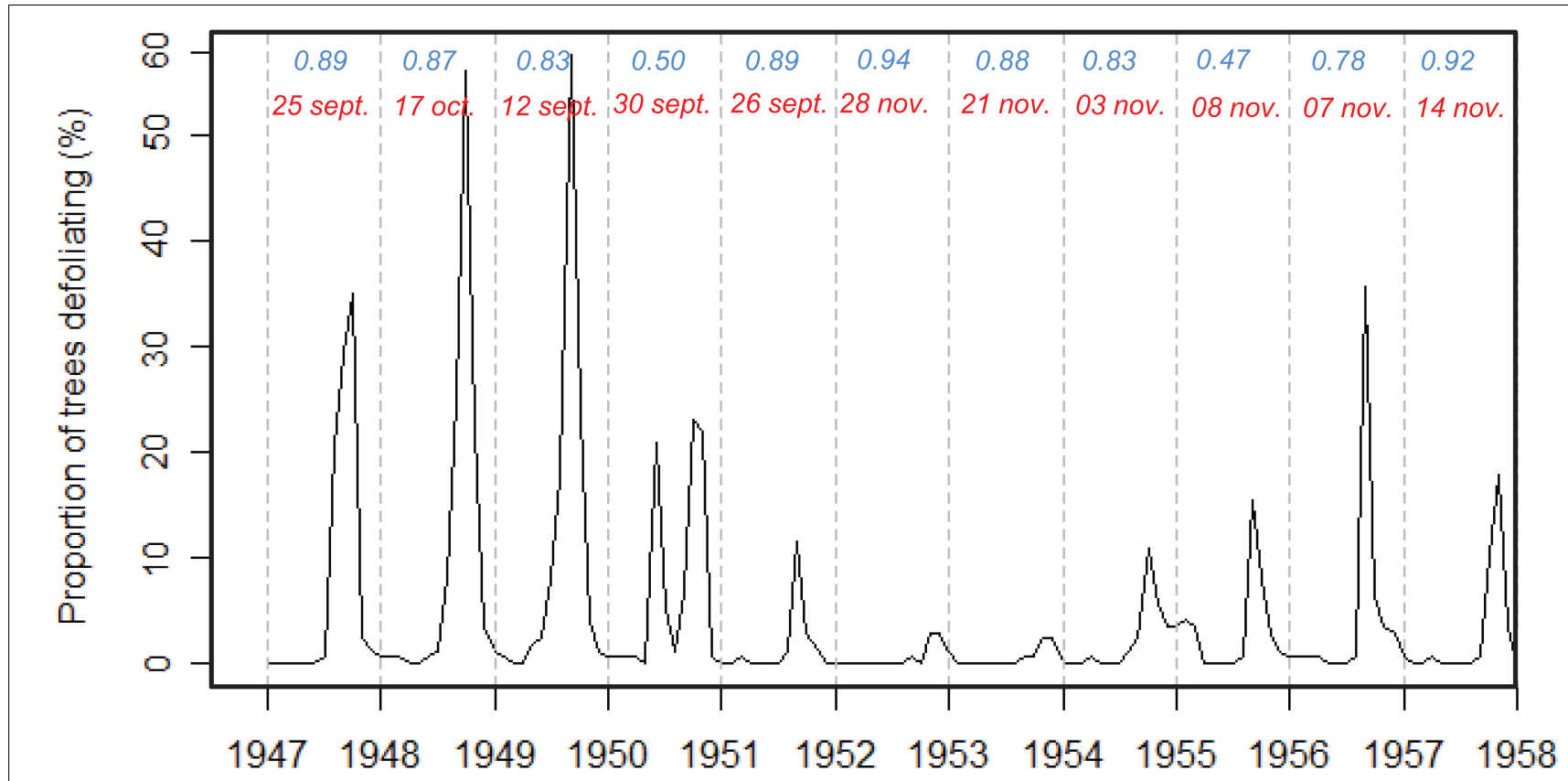

FIGURE 4 | Defoliation of $P$. balsamifera based on phenological observations from 1947 to 1957 . The result of circular statistics of defoliation for the population (194 trees) is given for each year. Specifically the strength of synchronicity between trees as given by the rho (in blue) and the mean peak date (in red).

(Figure 2) and the leaf unfolding occurs before the start of the rainy season (July, August, and September) and continues until October. Causes for asynchrony have not been thoroughly explored but differences in genetics, life history traits and habitat conditions encountered by individual trees may influence the way that populations as a whole experience environmental conditions, potentially leading to a diversity of responses among trees to the same environmental conditions (Thorson et al., 2014). Consistent lags in phenology are known to be genetic (te Beest et al., 2012). Indeed, given the diverse and consistent growing period, the environmental responses of $P$. balsamifera trees are variable and create diversity within the species. This lack of synchrony adds to the resilience of $P$. balsamifera populations. This way, as suggested by Fritts (2001) and Camarero et al. (2015), the concept of resilience is being addressed, not at the individual level of the organism, but rather at the population level and is similar to the general biological strategy of "bet hedging" (Cohen, 1966). The data we analyzed suggest that the $P$. balsamifera population is resilient (Figure 3). The lack of crossdating indicates that individuals of the same species in the same environment would react differently to a disturbance (Fritts, 2001). This will increase the resilience of the stand against unfavorable environmental fluctuations.

Many of the trees have less than 66 rings between 1948 and 2014, which shows that missing rings are common for the species. For the three trees that formed 66 rings between 1948 and 2014 (Figure 3), there was hardly any synchrony. This means that shifts (thus not synchronous) in leaf unfolding and defoliation and certainly different periods of cambial activity do have far-reaching consequences. This would be an advantage for the species in the face of the various changes that could occur in its environment, because the trees would react differently. Whether this is due to local site conditions, or genetics, is unclear.

Although at the individual level, tree rings provide a useful tool to analyze the resilience, this approach has seldom been used to evaluate resilience at the population level (DeClerck et al., 2006). Crossdating of ring-width series allows for the detection of synchrony between trees. The successful crossdating of ringwidth series denotes consistent and synchronous patterns of variation (Cook and Kairiukstis, 1990; Couralet et al., 2010) and indicates that the radial growth of different trees is controlled by a common external factor, e.g., rainfall and temperature (Couralet et al., 2010).

\section{CONCLUSION}

The studied population of $P$. balsamifera showed a synchronous phenology with a distinct defoliation period. Defoliation starts during the dry season in June-July with peaks during the rainy season in October-November, but the defoliation date varied across years and is consistent (annual ranks of trees according to leaf development and start of cambial activity do not change). Chronological series were built from wood samples collected from trees that were phenologically monitored. Xylem formation is seasonal, with cambial dormancy occurring during the dry season. The absence of crossdating between the chronological series of different trees suggests a varying response of $P$. balsamifera trees to environment. Based on the analyses carried out and the results obtained, $P$. balsamifera populations are likely resilient. 


\section{DATA AVAILABILITY STATEMENT}

The raw data supporting the conclusions of this article will be made available by the authors, without undue reservation.

\section{AUTHOR CONTRIBUTIONS}

BAI: literature review (lead), conceptualization (equal), formal analysis (lead), project administration (supporting), investigation (lead), methodology (lead), and writing-original draft (lead). JVdB, CC, AF, WH, NB, VD, CE, and TDM: conceptualization (equal), investigation (equal), supervision (equal), and writing review and editing (equal). HB: conceptualization (equal), funding acquisition (lead), investigation (equal), project administration (equal), supervision (equal), and writing original draft (equal). CK, MR, and EKY: conceptualization

\section{REFERENCES}

Alberton, B., da Torres, R. S., Cancian, L. F., Borges, B. D., Almeida, J., Mariano, G. C., et al. (2017). Introducing digital cameras to monitor plant phenology in the tropics: applications for conservation. Perspect. Ecol. Conserv. 15, 82-90. doi: 10.1016/j.pecon.2017.06.004

Aleman, J. C., Fayolle, A., Favier, C., Staver, A. C., Dexter, K. G., Ryan, C. M., et al. (2020). Floristic evidence for alternative biome states in tropical Africa. Proc. Natl. Acad. Sci. U. S. A. 117, 28183-28190. doi: 10.1073/pnas.2011515117

Angoboy Ilondea, B., Beeckman, H., Ouedraogo, D.-Y. O., Bourland, N., De Mil, T., Van Den Bulcke, J., et al. (2019). Une forte saisonnalité du climat et de la phénologie reproductive dans la forêt du Mayombe: l'apport des données historiques de la Réserve de Luki en République démocratique du Congo. Bois For. Trop. 341:39. doi: 10.19182/bft2019.341.a31753

Angoboy Ilondea, B., De Mil, T., Hubau, W., Van Acker, J., Van den Bulcke, J., Fayolle, A., et al. (2020). Towards improving the assessment of rainforest carbon: complementary evidence from repeated diameter measurements and dated wood. Dendrochronologia 62:125723. doi: 10.1016/j.dendro.2020.125723

Arno, J. (2001). "Gossweilerodendron balsamiferum," in A Guide to Useful Woods of the World, eds J. H. Flynn Jr. and C. D. Holder (Madison, WI: Forest Products Society), 260-261.

Beeckman, H. (2016). Wood anatomy and trait-based ecology. IAWA J. 37, 127151. doi: 10.1163/22941932-20160127

Borchert, R. (1998). "Responses of tropical trees to rainfall seasonality and its long-term changes," in Potential Impacts of Climate Change on Tropical Forest Ecosystems, ed. A. Markham (Dordrecht: Springer Netherlands), 241-253. doi: 10.1007/978-94-017-2730-3_10

Bréda, N., Huc, R., Granier, A., and Dreyer, E. (2006). Temperate forest trees and stands under severe drought: a review of ecophysiological responses, adaptation processes and long-term consequences. Ann. For. Sci. 63, 625-644. doi: 10.1051/ forest:2006042

Bunn, A. G. (2008). A dendrochronology program library in R (dplR). Dendrochronologia 26, 115-124. doi: 10.1016/j.dendro.2008. 01.002

Bunn, A. G. (2010). Statistical and visual crossdating in R using the dplR library. Dendrochronologia 28, 251-258. doi: 10.1016/j.dendro.2009.12.001

Bush, E. R., Abernethy, K. A., Jeffery, K., Tutin, C., White, L., Dimoto, E., et al. (2017). Fourier analysis to detect phenological cycles using long-term tropical field data and simulations. Methods Ecol. Evol. 8, 530-540. doi: 10.1111/2041210X.12704

Camarero, J. J., Gazol, A., Sangüesa-Barreda, G., Oliva, J., and Vicente-Serrano, S. M. (2015). To die or not to die: early warnings of tree dieback in response to a severe drought. J. Ecol. 103, 44-57. doi: 10.1111/1365-2745. 12295

Carrer, M. (2011). Individualistic and time-varying tree-ring growth to climate sensitivity. PLoS One 6:e22813. doi: 10.1371/journal.pone.0022813 (equal), investigation (equal), and writing - review and editing (equal). All authors contributed to the article and approved the submitted version.

\section{FUNDING}

This study was supported by the Belgian Scientific Affairs (Belspo-BRAIN program axis 4 project: BR/143/A3/HERBAXYL AREDD) and the Belgian Development Cooperation (DGDRMCA framework agreement: PilotMAB).

\section{ACKNOWLEDGMENTS}

We are grateful to the management and field team of INERALUKI and the Royal Museum for Central Africa.

Cohen, D. (1966). Optimizing reproduction in a randomly varying environment. J. Theor. Biol. 12, 119-129. doi: 10.1016/0022-5193(66)90188-3

Cook, E. R., and Kairiukstis, L. A. (eds.). (1990). “A conceptual linear aggregate model for tree-rings," in Methods of Dendrochronology: Applications in the Environmental Sciences (Dordrecht: Kluwer Academic Publishers).

Couralet, C., Sterck, F. J., Sass-Klaassen, U., Acker, J. V., and Beeckman, H. (2010). Species-specific growth responses to climate variations in understory trees of a Central African Rain Forest. Biotropica 42, 503-511. doi: 10.1111/j.1744-7429. 2009.00613.x

Couralet, C., Van den Bulcke, J., Ngoma, L., Van Acker, J., and Beeckman, H. (2013). Phenology in functional groups of central african rainforest trees. J. Trop. For. Sci. 25, 361-374.

Davies, S. J., and Ashton, P. S. (1999). Phenology and fecundity in 11 sympatric pioneer species of Macaranga (Euphorbiaceae)in Borneo. Am. J. Bot. 86, 17861795. doi: $10.2307 / 2656675$

De Mil, T., Angoboy Ilondea, B., Maginet, S., Duvillier, J., Van Acker, J., Beeckman, H., et al. (2017). Cambial activity in the understory of the Mayombe forest, DR Congo. Trees 31, 49-61. doi: 10.1007/s00468-016-1454-x

De Mil, T., Hubau, W., Angoboy Ilondea, B., Rocha Vargas, M. A., Boeckx, P., Steppe, K., et al. (2019). Asynchronous leaf and cambial phenology in a tree species of the Congo Basin requires space-time conversion of wood traits. Ann. Bot. 124, 245-253. doi: 10.1093/aob/mcz069

De Mil, T., Vannoppen, A., Beeckman, H., Van Acker, J., and Van den Bulcke, J. (2016). A field-to-desktop toolchain for X-ray CT densitometry enables tree ring analysis. Ann. Bot. 117, 1187-1196. doi: 10.1093/aob/mcw063

De Ridder, M., Trouet, V., Van den Bulcke, J., Hubau, W., Van Acker, J., and Beeckman, H. (2013). A tree-ring based comparison of Terminalia superba climate-growth relationships in West and Central Africa. Trees 27, 1225-1238. doi: 10.1007/s00468-013-0871-3

DeClerck, F. A. J., Barbour, M. G., and Sawyer, J. O. (2006). Species richness and stand stability in conifer forests of the Sierra Nevada. Ecology 87, 2787-2799.

Enquist, B. J., and Leffler, A. J. (2001). Long-term tree ring chronologies from sympatric tropical dry-forest trees: individualistic responses to climatic variation. J. Trop. Ecol. 17, 41-60.

Fayolle, A., Swaine, M. D., Bastin, J.-F., Bourland, N., Comiskey, J. A., Dauby, G., et al. (2014). Patterns of tree species composition across tropical African forests. J. Biogeogr. 41, 2320-2331. doi: 10.1111/jbi.12382

Fétéké, F., Fayolle, A., Dainou, K., Bourland, N., Dié, A., Lejeune, P., et al. (2016). Variations saisonnières de la croissance diamétrique et des phénologies foliaire et reproductive de trois espèces ligneuses commerciales d'Afrique Centrale. Bois For. Trop. 330:3. doi: 10.19182/bft2016.330.a31315

Fritts, H. C. (2001). Tree Rings and Climate. Caldwell, NJ: The Blackburn Press.

Gärtner, H., and Nievergelt, D. (2010). The core-microtome: a new tool for surface preparation on cores and time series analysis of varying cell parameters. Dendrochronologia 28, 85-92. doi: 10.1016/j.dendro.2009.09.002 
Herrera-Ramirez, D., Andreu-Hayles, L., del Valle, J. I., Santos, G. M., and Gonzalez, P. L. M. (2017). Nonannual tree rings in a climate-sensitive Prioria copaifera chronology in the Atrato River, Colombia. Ecol. Evol. 7, 6334-6345. doi: 10.1002 /ece3.2905

Holmes, R. L. (1983). Computer-assisted quality control in tree-ring dating and measurement. Tree Ring Bull. 43, 69-78.

Hubau, W., De Mil, T., Van den Bulcke, J., Phillips, O. L., Angoboy Ilondea, B., Van Acker, J., et al. (2019). The persistence of carbon in the African forest understory. Nat. Plants 5, 133-140. doi: 10.1038/s41477-018-0316-5

Hubau, W., Lewis, S. L., Phillips, O. L., Affum-Baffoe, K., Beeckman, H., CuníSanchez, A., et al. (2020). Asynchronous carbon sink saturation in African and Amazonian tropical forests. Nature 579, 80-87. doi: 10.1038/s41586-0202035-0

Kikuzawa, K., and Lechowicz, M. J. (2011). "Ecosystem perspectives on leaf longevity," in Ecology of Leaf Longevity, Ecological Research Monographs, eds K. Kikuzawa and M. J. Lechowicz (Tokyo: Springer), 109-119. doi: 10.1007/9784-431-53918-6_10

Lewis, S. L., Wheeler, C. E., Mitchard, E. T. A., and Koch, A. (2019). Restoring natural forests is the best way to remove atmospheric carbon. Nature 568, 25-28. doi: 10.1038/d41586-019-01026-8

Lisi, C. S., Fo, M. T., Botosso, P. C., Roig, F. A., Maria, V. R. B., Ferreira-Fedele, L., et al. (2008). Tree-ring formation, radial increment periodicity, and phenology of tree species from a seasonal semi-deciduous forest in Southeast Brazil. IAWA J. 29, 189-207. doi: 10.1163/22941932-90000179

Lloret, F., Siscart, D., and Dalmases, C. (2004). Canopy recovery after drought dieback in holm-oak Mediterranean forests of Catalonia (NE Spain). Glob. Change Biol. 10, 2092-2099. doi: 10.1111/j.1365-2486.2004.00870.x

Lubini, A. (1997). La végétation de la Réserve de biosphère de Luki au Mayombe (RD. Congo). Opera Bot. Belg. 10:155.

Malaisse, F. (1964). Contribution à l'étude des hêtraies d'Europe occidentale: Note 4: Quelques observations phénologiques de hêtraies en 1963. Bullet. Soc. Roy. Bot. Belgique/Bullet. Konink. Bel. Botan. Veren. 97, 85-97. Available online at: http://hdl.handle.net/2268/220730

Manoli, G., Ivanov, V. Y., and Fatichi, S. (2018). Dry-season greening and water stress in amazonia: the role of modeling leaf phenology. J. Geophys. Res. Biogeosci. 123, 1909-1926. doi: 10.1029/2017JG004282

Meunier, Q., Moumbogou, C., and Doucet, J.-L. (2015). Les Arbres Utiles du Gabon. Gembloux: Presses Agronomiques de Gembloux.

Millar, C. I., Stephenson, N. L., and Stephens, S. L. (2007). Climate change and forests of the future: managing in the face of uncertainty. Ecol. Appl. 17, 2145-2151. doi: 10.1890/06-1715.1

Morel, H., Mangenet, T., Beauchêne, J., Ruelle, J., Nicolini, E., Heuret, P., et al. (2015). Seasonal variations in phenological traits: leaf shedding and cambial activity in Parkia nitida Miq. and Parkia velutina Benoist (Fabaceae) in tropical rainforest. Trees 29, 973-984. doi: 10.1007/s00468-015-1177-4

Morellato, L. P. C., Talora, C. D., Takahasi, A., Bencke, C. C., Romera, C. E. E., and Zipparo, V. (2000). Phenology of Atlantic rain forest trees: a comparative study. Biotropica 32, 811-823. doi: 10.1111/j.1744-7429.2000.tb00620.x

Newstrom, L. E., Frankie, G. W., and Baker, H. G. (1994). A new classification for plant phenology based on flowering patterns in Lowland tropical rain forest trees at La Selva, Costa Rica. Biotropica 26, 141-159. doi: 10.2307/2388804

Peel, M. C., Finlayson, B. L., and Mcmahon, T. A. (2007). Updated world map of the Köppen-Geiger climate classification. Hydrol. Earth Syst. Sci. Discuss. 4, 439-473. doi: 10.5194/hessd-4-439-2007

Pumijumnong, N., and Buajan, S. (2013). Seasonal cambial activity of five tropical tree species in central Thailand. Trees 27, 409-417. doi: 10.1007/s00468-0120794-4

Pumijumnong, N., and Park, W.-K. (1999). Vessel chronologies from teak in Northern Thailand and their climatic signal. IAWA J. 20, 285-294. doi: 10.1163/ 22941932-90000691

R Core Team (2016). A Language and Environment for Statistical Computing. Vienna: R Foundation for statistical computing.

Reich, P. B. (1995). Phenology of tropical forests: patterns, causes, and consequences. Can. J. Bot. 73, 164-174. doi: 10.1139/b95-020

Ryan, C. M., Williams, M., Grace, J., Woollen, E., and Lehmann, C. E. R. (2017). Pre-rain green-up is ubiquitous across southern tropical Africa: implications for temporal niche separation and model representation. New Phytol. 213, 625-633. doi: $10.1111 /$ nph. 14262
Sénéchal, J., Kabala, M., and Fournier, F. (1989). Revue des Connaissances sur le Mayombe. Paris: UNESCO.

Seo, J.-W., Eckstein, D., and Schmitt, U. (2007). The pinning method: from pinning to data preparation. Dendrochronologia 25, 79-86. doi: 10.1016/j.dendro.2007. 04.001

Sevanto, S., Mcdowell, N. G., Dickman, L. T., Pangle, R., and Pockman, W. T. (2014). How do trees die? A test of the hydraulic failure and carbon starvation hypotheses. Plant Cell Environ. 37, 153-161. doi: 10.1111/pce. 12141

Singh, D. N., and Venugopal, N. (2011). Cambial activity and annual rhythm of xylem production of Pinus kesiya Royle ex. Gordon (Pinaceae) in relation to phenology and climatic factors growing in sub-tropical wet forest of North East India. Flora Morphol. Distrib. Funct. Ecol. Plants 206, 198-204. doi: 10.1016/j. flora.2010.04.021

Swetnam, T. W., Allen, C. D., and Betancourt, J. L. (1999). Applied historical ecology: using the past to manage for the future. Ecol. Appl. 9, 1189-1206. doi: 10.1890/1051-0761(1999)009[1189:AHEUTP]2.0.CO;2

Tang, J., Liu, R., Zhang, Y.-L., Liu, M.-Z., Hu, Y.-F., Shao, M.-J., et al. (2018). Correction: corrigendum: application of machine-learning models to predict tacrolimus stable dose in renal transplant recipients. Sci. Rep. 8:46936. doi: $10.1038 /$ srep46936

te Beest, M., Le Roux, J. J., Richardson, D. M., Brysting, A. K., Suda, J., Kubešová, M., et al. (2012). The more the better? The role of polyploidy in facilitating plant invasions. Ann. Bot. 109, 19-45. doi: 10.1093/aob/mcr277

Thorson, J. T., Scheuerell, M. D., Buhle, E. R., and Copeland, T. (2014). Spatial variation buffers temporal fluctuations in early juvenile survival for an endangered Pacific salmon. J. Anim. Ecol. 83, 157-167.

Trouet, V., Mukelabai, M., Verheyden, A., and Beeckman, H. (2012). Cambial growth season of brevi-deciduous brachystegia spiciformis trees from South Central Africa restricted to less than four months. PLoS One 7:e47364. doi: 10.1371/journal.pone.0047364

Wagner, F., Rossi, V., Baraloto, C., Bonal, D., Stahl, C., and Hérault, B. (2014). Are commonly measured functional traits involved in tropical tree responses to climate? Int. J. Ecol. 1:11. doi: 10.1155/2014/389409

Wigley, T. M. L., Briffa, K. R., and Jones, P. D. (1984). On the average value of correlated time series, with applications in dendroclimatology and hydrometeorology. J. Clim. Appl. Meteor. 23, 201-213. doi: 10.1175/152004501984023<0201:OTAVOC<2.0.CO;2

Worbes, M. (1999). Annual growth rings, rainfall-dependent growth and long-term growth patterns of tropical trees from the Caparo Forest Reserve in Venezuela. J. Ecol. 87, 391-403. doi: 10.1046/j.1365-2745.1999. 00361.x

Zang, C., Hartl-Meier, C., Dittmar, C., Rothe, A., and Menzel, A. (2014). Patterns of drought tolerance in major European temperate forest trees: climatic drivers and levels of variability. Glob. Change Biol. 20, 3767-3779. doi: 10.1111/gcb. 12637

Conflict of Interest: NB was employed by the company Resources \& Synergies Development Pte. Ltd.

The remaining authors declare that the research was conducted in the absence of any commercial or financial relationships that could be construed as a potential conflict of interest.

Publisher's Note: All claims expressed in this article are solely those of the authors and do not necessarily represent those of their affiliated organizations, or those of the publisher, the editors and the reviewers. Any product that may be evaluated in this article, or claim that may be made by its manufacturer, is not guaranteed or endorsed by the publisher.

Copyright (C) 2021 Angoboy Ilondea, Beeckman, Van Acker, Van den Bulcke, Fayolle, Couralet, Hubau, Kafuti, Rousseau, Kaka di-Makwala, Bourland, Deklerck, Kasongo Yakusu, Ewango and De Mil. This is an open-access article distributed under the terms of the Creative Commons Attribution License (CC BY). The use, distribution or reproduction in other forums is permitted, provided the original author(s) and the copyright owner(s) are credited and that the original publication in this journal is cited, in accordance with accepted academic practice. No use, distribution or reproduction is permitted which does not comply with these terms. 